\title{
Research on E-commerce Entrepreneurship Education in Higher Vocational College
}

\author{
Xie Rong \\ Ningbo City Vocational and Technical College \\ Business School \\ Ningbo, China
}

\begin{abstract}
Under the background of mass entrepreneurship and innovation, with the rapid development of e-commerce, more and more college students choose e-commerce entrepreneurship. Therefore, combining e-commerce with entrepreneurship education, making full use of the advantages of e-commerce, cultivating students' entrepreneurial awareness and innovative spirit, and improving students' ability of innovation and entrepreneurship have become important topics for cultivating entrepreneurial talents in higher vocational colleges. This paper analyzes the current situation of e-commerce entrepreneurship education for college students in higher vocational colleges, and proposes an e-commerce entrepreneurship education curriculum system that is applicable to higher vocational colleges and emphasizes both theory and practice. This paper makes suggestions for e-commerce entrepreneurship awareness training, and proposes to improve the incentive mechanism of e-commerce entrepreneurship, the construction of teaching staff, the precision assistance to entrepreneurial students, and fully use resources inside and outside the school to organize students to practice entrepreneurship.
\end{abstract}

Keywords-Higher vocational colleges; E-commerce; entrepreneurship education; Curriculum system; E-commerce entrepreneurship class

\section{INTRODUCTION}

Under the background of mass entrepreneurship and innovation, with the rapid development of e-commerce, more and more college students choose E-commerce Entrepreneurship. Compared with other traditional forms of entrepreneurship, e-commerce entrepreneurship has the advantages of low entrepreneurial cost, small entrepreneurial risk, flexible entrepreneurial form, wide market coverage, and free entrepreneurial time. Therefore, college students' entrepreneurship will give priority to e-commerce entrepreneurship [1]. According to the 41st Statistical Report on China's Internet Development Status released by China Internet Network Information Center CNNIC, as of December 2017, the number of Chinese Internet users reached 772 million, of which online shopping users reached 533 million, accounting for netizens. The ratio is $69.1 \%$. According to the data of the National Bureau of Statistics e-commerce trading platform, in 2017, China's e-commerce transaction volume reached 29.16 trillion yuan, an increase of $11.7 \%$. It can be seen from these data that the e-commerce market has great potential, both in terms of the size of Internet users and the scale of e-commerce transactions.

Therefore, combining e-commerce with entrepreneurship education, making full use of the advantages of e-commerce, cultivating students' entrepreneurial awareness and innovative spirit, and improving students' ability to innovate and innovate has become an important factor in cultivating entrepreneurial talents in higher vocational colleges.

\section{THE STATUS QUO OF E-COMMERCE ENTREPRENEURSHIP EDUCATION IN HIGHER VOCATIONAL COLLEGES}

Guided by a series of national policies such as "Public Entrepreneurship Innovation" and "Several Opinions on Deepening the Reform of Vocational Education and Teaching Reform to Improve the Quality of Talent Cultivation", higher vocational colleges actively carry out entrepreneurship education and set up entrepreneurship colleges to establish entrepreneurship education. For all students in school, more and more students choose to start a business, and entrepreneurship education has made unprecedented progress.

At present, China's entrepreneurial education mainly has two modes: "the theoretical type of undergraduate colleges" and "practical type of higher vocational colleges" [2]. The two entrepreneurial education models have their own advantages and disadvantages, as shown in Table 1: 
TABLE I. COMPARISON OF ENTREPRENEURIAL EDUCATION MODELS IN COLLEGES AND UNIVERSITIES

\begin{tabular}{|c|c|c|c|}
\hline $\begin{array}{l}\text { Entrepreneurship } \\
\text { education model }\end{array}$ & Characteristics & advantage & Disadvantage \\
\hline $\begin{array}{c}\text { Theoretical type of } \\
\text { undergraduate colleges and } \\
\text { Universities }\end{array}$ & $\begin{array}{l}\text { Heavy theory, light } \\
\text { practice }\end{array}$ & $\begin{array}{l}\text { easy to use; } \\
\text { Less time and effort; } \\
\text { Students can master entrepreneurial } \\
\text { processes and basic skills in a short } \\
\text { period of time. }\end{array}$ & $\begin{array}{l}\text { Theoretical teaching or experimental software simulation or artificial } \\
\text { simulation can not show the complexity of the real entrepreneurial } \\
\text { environment, which is not conducive to the real improvement of } \\
\text { entrepreneurial ability. }\end{array}$ \\
\hline $\begin{array}{l}\text { Practical type of Higher } \\
\text { Vocational Colleges }\end{array}$ & $\begin{array}{l}\text { Practice, light } \\
\text { theory }\end{array}$ & $\begin{array}{l}\text { Be able to make real profits and } \\
\text { gain a sense of entrepreneurial } \\
\text { accomplishment; } \\
\text { Students can quickly and } \\
\text { comprehensively master } \\
\text { entrepreneurial skills; } \\
\text { Accumulate entrepreneurial } \\
\text { experience }\end{array}$ & $\begin{array}{l}\text { Complex management; } \\
\begin{array}{c}\text { Students may therefore not pay attention to theoretical study, leading to } \\
\text { utilitarian education. }\end{array}\end{array}$ \\
\hline
\end{tabular}

No matter whether it is an undergraduate college or a higher vocational college, it can not be "re-theory, light practice", nor can it be "heavy practice, light theory". The cultivation of higher education talents is based on the "theoretical application" and requires students to use scientific theories to solve practical problems on the premise that theoretical knowledge is sufficient.

With the advent of the "Internet + " era and the rapid development of e-commerce, more and more college students choose e-commerce entrepreneurship, and the success rate of entrepreneurship is constantly improving. E-commerce entrepreneurship education is to integrate e-commerce into entrepreneurship education in the process of cultivating entrepreneurial talents. Based on e-commerce, build a platform for student entrepreneurship, conduct e-commerce entrepreneurship basic education, e-commerce entrepreneurship training, e-commerce entrepreneurship, etc. To achieve the educational goal of cultivating students' entrepreneurial awareness and innovation spirit, improving students' ability of innovation and entrepreneurship, and cultivating entrepreneurial talents. At present, most of the vocational education carried out by higher vocational colleges is based on the traditional entrepreneurial education model, and there is no systematic integration of e-commerce into entrepreneurship education.

Some higher vocational colleges have integrated e-commerce into entrepreneurship education, but over-emphasized the online Taobao shop, over-emphasis on actual combat, weakening e-commerce entrepreneurship theory education, and equating online Taobao shop and e-commerce startup. Taobao is one of the forms of e-commerce entrepreneurship and the simplest form of entrepreneurship. E-commerce entrepreneurship education can choose the practical education model of Taobao to open a store. At the same time, it should cultivate students' awareness of innovation and entrepreneurship, and improve entrepreneurial literacy and entrepreneurial skills by learning entrepreneurial theoretical knowledge.
III. THE CONSTRUCTION OF " PAY EQUAL ATTENTION TO ETHICS AND PRACTICE " E-COMMERCE ENTREPRENEURSHIP EDUCATION CURRICULUM SYSTEM IN VOCATIONAL COLLEGES

In order to improve the entrepreneurial awareness and entrepreneurial ability of college students in higher vocational colleges, e-commerce entrepreneurship education can build "e-commerce entrepreneurial awareness enlightenment course", "e-commerce entrepreneurship skills course", "e-commerce entrepreneurship training course" and "e-commerce entrepreneurship practice" Course "four-tiered curriculum system.

\section{A. E-commerce entrepreneurial awareness enlightenment course}

In the E-Commerce Entrepreneurship Enhancement Course, various forms of entrepreneurship lectures, entrepreneurial story pools, entrepreneurial salons and clubs are invited to invite off-campus entrepreneurial instructors to preach and share entrepreneurial experiences and career plans in various fields, to inspire and inspire students' creative awareness. To understand the difficulties and risks of starting a business, and to ignite the entrepreneurial passion of students with certain entrepreneurial foundations and conditions.

\section{B. E-commerce entrepreneurship skills course}

E-Commerce Entrepreneurship Skills Program conducts general entrepreneurial instructional education around student entrepreneurship project management, focusing on e-commerce core skills such as online product photography, image processing, network marketing and planning, network operations, and business registration, taxation law, entrepreneurship policy, finance Entrepreneurial skills education in management, personnel incentives and management, project and market management.

\section{E-commerce entrepreneurship training course}

The e-commerce entrepreneurship training course conducts simulation and entrepreneurship learning through the entrepreneurial sandbox, and discovers the system, evaluates the system, realizes the system through the entrepreneurial opportunity, simulates the business operation, and enhances the entrepreneurial skills. At the same time, students are encouraged to participate in the Challenge Cup, Internet + and other entrepreneurial competitions to enhance the overall quality of entrepreneurship. Combine e-commerce entrepreneurship with student professionalism to identify 
entrepreneurial projects, select entrepreneurial products or services.

\section{E-commerce entrepreneurship practical course}

The E-Commerce Entrepreneurship Practical Course is designed to allow students to form an entrepreneurial team and register a company with 3-5 people. Complete a real entrepreneurial project from market research, product selection, platform selection and construction, project implementation and operations. Teams can communicate and compete with each other [4]. Through practical drill courses, students can combine entrepreneurship courses, theoretical knowledge courses and skills courses to experience real entrepreneurial processes, gain real entrepreneurial experience and lessons, and lay the foundation for future entrepreneurship.

The contents of the e-commerce entrepreneurship education curriculum group construction are as follows:

TABLE II. E-COMMERCE ENTREPRENEURSHIP EDUCATION CURRICULUM SYSTEM

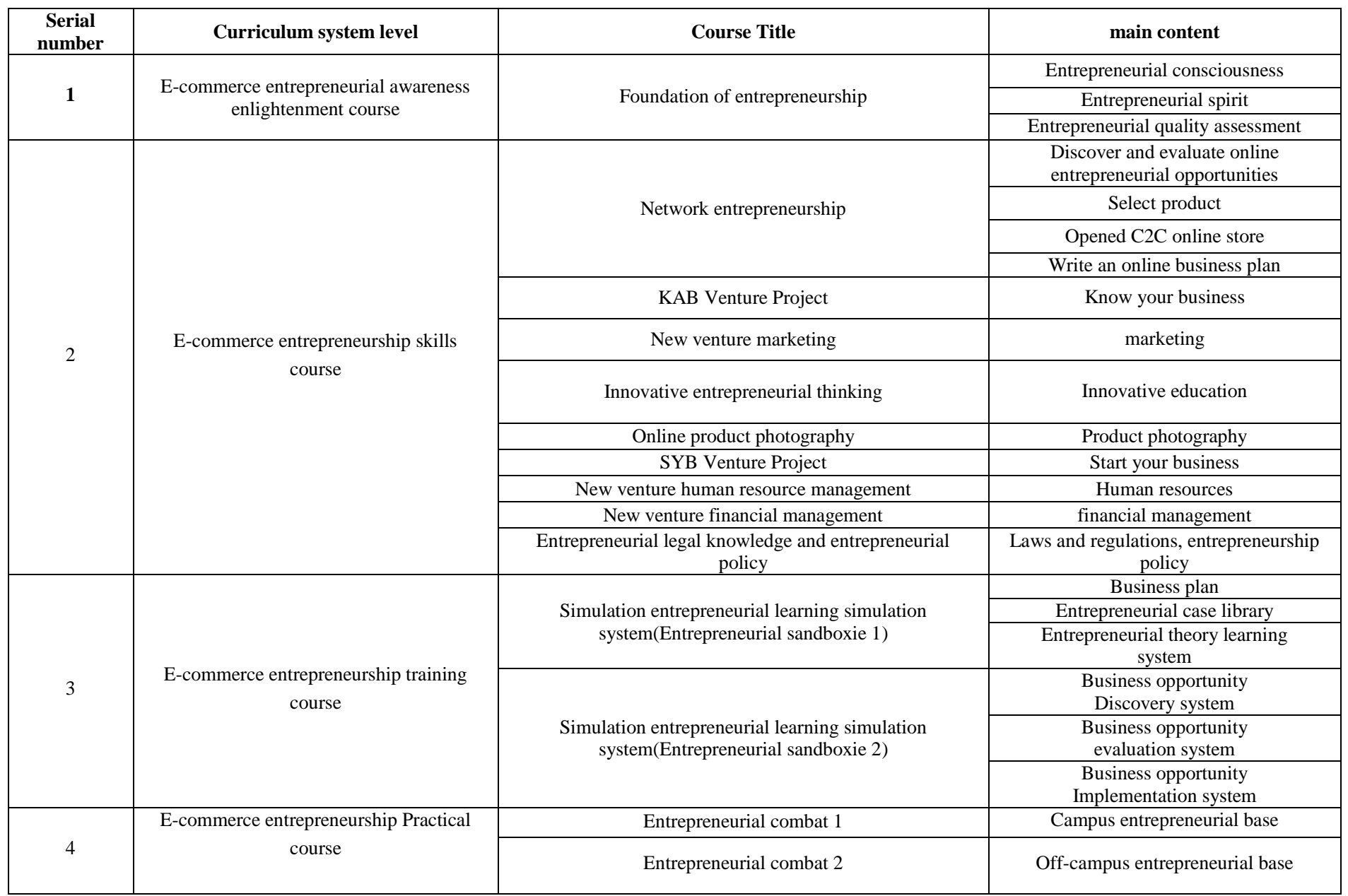

\section{SUGGESTIONS ON E-COMMERCE ENTREPRENEURSHIP EDUCATION IN HighER VOCATIONAL COLLEGES}

\section{A. Cultivating e-commerce entrepreneurial awareness and creating an entrepreneurial atmosphere}

Higher vocational colleges can set up compulsory courses such as e-commerce and entrepreneurship, so that every student can know and understand e-commerce, cultivate entrepreneurial awareness, and guide students to form e-commerce entrepreneurial awareness. Compared with traditional entrepreneurship, e-commerce entrepreneurship has the advantages of low cost, low risk and high efficiency, which is very suitable for college students to start a business.
Therefore, when a student is a freshman, a higher vocational college can stimulate students' entrepreneurial awareness by offering entrepreneurial foundation courses, holding relevant e-commerce entrepreneurship lectures, and sharing e-commerce entrepreneurial success stories [5]; through student associations, e-commerce associations, entrepreneurship associations, Entrepreneurial street, campus entrepreneurial park and other forms, so that students interested in e-commerce, entrepreneurial intentions can have the opportunity to share and share, create a good entrepreneurial atmosphere. 


\section{B. Stimulating students' entrepreneurial enthusiasm and improving the incentive mechanism for e-commerce entrepreneurship}

In order to stimulate students' entrepreneurial enthusiasm, higher vocational colleges should improve the incentive mechanism for students' e-commerce entrepreneurship. Priority is given to students who have achieved the key achievements of innovation and entrepreneurship in various evaluations and recommendations. According to the credits such as innovative credits, skill credits, and quality credits in higher vocational colleges, students are encouraged to actively carry out innovation and entrepreneurship in and out of class, and give credits for papers, patents, self-employment, participation in research projects, and project experiments. Any other elective credits for the first class are credited to the student's total credits and grades. Encourage students to form scientific research and technology groups across disciplines and colleges to carry out innovative practices and form entrepreneurial teams to conduct entrepreneurial activities. Guide students to actively participate in innovation and entrepreneurship activities, and promote the development of students' innovative and entrepreneurial capabilities. Students in the centralized training stage are allowed to replace the professional course credits with the training course credits, and the original professional degree and diploma are awarded after graduation; the flexible academic system can be applied to allow students to apply for suspension of business within the longest period of employment. Develop a certificate system for college students' entrepreneurship education, issue a certificate of level to qualified university students, and link with the entrepreneurial support policy. Establish and improve the assessment and reward of teachers to guide students' innovation and entrepreneurial activities. The school has tilted the entrepreneurial tutors in terms of performance evaluation, job title promotion, job appointment, etc., and guided the students' innovation and entrepreneurship as the basic conditions for teachers to recruit high-level positions, further intensified the rewards for students' scientific research teachers, and encouraged more teachers to be active. Committed to the school entrepreneurship talent training practice activities, and actively commend the outstanding performance of teachers in innovation and entrepreneurship education.

\section{Strengthening the cooperation between schools and enterprises, and strengthening the construction of e-commerce entrepreneurship education teachers}

By increasing the cooperation between schools and enterprises, we will recruit a team of entrepreneurial instructors with practical experience, especially in the field of e-commerce, to improve the e-commerce faculty team. At the same time, it cooperates with relevant enterprises, adopts different forms to absorb high-level outstanding entrepreneurs, and builds a team of entrepreneurial colleges and universities cooperation instructors and entrepreneurial tutors [6]. Provide one-stop entrepreneurial services such as market research, planning and design, project entry incubation, project financing, project roadshow, etc. in the form of corporate entrepreneurship tutor system, set up a venture development fund, and regularly launch a large-scale event of the TV version of the Entrepreneurship Hero. Effective docking of projects, funds and teams. Through the alumni channel, we select outstanding entrepreneurs with typical representativeness, and jointly build a team of entrepreneurial tutors who are mainly based on off-campus combat-oriented outstanding entrepreneurial tutors and on-campus entrepreneurship education guidance. Through centralized lectures and one-on-one tutoring, E-commerce entrepreneurs provide entrepreneurship education and entrepreneurship support.

\section{Accurately helping e-commerce entrepreneurs and setting up e-commerce entrepreneurship classes}

In order to accurately help e-commerce entrepreneurs, e-commerce entrepreneurship education in higher vocational colleges can set up e-commerce entrepreneurship when students choose a professional direction in the sophomore year or when they are internship in the third semester, attracting interest in e-commerce or entrepreneurship. The classmates form an e-commerce startup class. E-commerce entrepreneurship courses can be undertaken by e-commerce colleges or entrepreneurship colleges to provide students with centralized and targeted training and teaching to improve students' entrepreneurial awareness, entrepreneurial theory and entrepreneurial skills.

\section{E. Making full use of resources inside and outside the school to organize students to practice entrepreneurship}

Higher vocational colleges should make full use of local and industry resources and other off-campus resources for entrepreneurial practice. It can let enterprises enter the campus, provide entrepreneurial projects for students, conduct entrepreneurial practice, and allow students to enter the off-campus cooperative enterprises to conduct entrepreneurial practice and accumulate entrepreneurial experience. Taking Ningbo City Vocational and Technical College as an example, we can make full use of Ningbo's advantages as an e-commerce pilot city and the first batch of cross-border e-commerce pilot cities, explore off-campus resources, and carry out entrepreneurial practice. For example, you can use the cross-border e-commerce platform of Ningbo Bonded Zone to let students practice entrepreneurship. At the same time, campus resources can also be fully utilized. Professional teachers in the school set up e-commerce studios, such as photography studios, photo processing studios, e-commerce operation studios, etc., to attract e-commerce entrepreneurs to use their spare time to conduct entrepreneurial practice, enhance e-commerce entrepreneurial skills, and accumulate entrepreneurial practice experience.

\section{CONCLUSION}

E-commerce entrepreneurship is an important form of college students' entrepreneurship. Higher vocational colleges should actively explore strategies and ways to adapt to e-commerce entrepreneurship education for college students in higher vocational colleges, and continuously cultivate high-quality entrepreneurial talents. 


\section{REFERENCES}

[1] Xie Rong. Discussion on entrepreneurial education of college students in applied undergraduate colleges. Heilongjiang Textile [J]. 2013, 12.

[2] Shi Wei. Research and practice of undergraduate e-commerce entrepreneurship education, e-commerce [J].2013, 4.

[3] Zhang zuowei. Research on "X+1" Collaborative Innovation Training Mode of E-commerce Talents in Higher Vocational Colleges. Vocational and technical education [J], 2015, 36 (26): 8-12.

[4] Xie Yincheng, Tian Zhenping. Discussion on College Students' E-commerce Entrepreneur Innovation Education. Vocational Education Communication [J]. 2017, 17:47-51.

[5] Liu Chang. Exploring the path of innovation and entrepreneurship education in higher vocational colleges. Vocational Education Forum [J], 2017, 3.

[6] Li Chunli. Coordination of e-commerce entrepreneurship education and employment education in higher vocational colleges. Vocational Education Forum [J], 2017.27. 